\title{
A.P. Наврузов Дискуссии об иджтихаде и таклиде среди дагестанских улемов первой четверти XX в.
}

Для понимания острых идейных споров о религиозной традиции, идущих в постсоветское время между соперничающими группировками мусульманского духовенства на Северном Кавказе полезно обратиться в относительно недавнее прошлое 1 . Конечно, многое здесь определяет своеобразный современный исторический контекст. Ошибочно было бы сводить все к политической борьбе за власть и ресурсы, забывая про исламскую составляющую этих споров. Дискуссии такого рода не новы в исламе и, в частности, для мусульман Северного Кавказа и Дагестана. В последний раз они шли в другую переломную эпоху в истории региона - в первой четверти XX в. Благодаря сохранившимся в частных собраниях и архивных коллекциях Дагестана полемическим рукописным трактатам и статьям из исламской прессы, ненадолго появившейся тогда в регионе, мы имеем уникальную возможность понять богословскую составляющую и сам язык этой периодически возобновляющейся дискуссии. Характерно, что в то же примерно время подобные дискуссии шли среди мусульманских элит российского Крыма, Волго-Уральского региона, Западной Сибири и Средней Азии. К сожалению, поскольку тексты эти написаны на арабском, нередко в виде рукописей, полны богословских аллюзий и малодоступны, они еще не служили предметом исследования историков, а в большинстве своем не введены в научный оборот. Ниже мы предлагаем один из первых опытов текстологического анализа богословских споров об отношении северокавказских улемов позднего имперского и раннего советского времени к иджтихаду и таклиду в исламе.

Особенностью изучаемого периода было то, что эти споры впервые переходят из рукописной переписки в прессу, правда во многом сохраняя при этом прежнюю форму и содержание. Первой (и последней) газетой на литературном арабском языке на Северном Кавказе

1 | Работа написана при поддержке Программы Президиума РАН «Традиции и инновации в истории и культуре» по проекту «Ислам в культуре народов России» (руководитель А.А. Ярлыкапов (2012-2014)). 
стала «Джаридат Дагистан» («Газета Дагестан»), издававшаяся в административном центре Дагестанской области - городе Темир-ХанШура (современный Буйнакск) с 7 (20) января 1913 г. до 15 января 1919 г., последний год - под названием «Дагестан». Вплоть до начала Гражданской войны она распространялась по подписке в Дагестанской, Терской и Кубанской областях Северного Кавказа, на Ставрополье, в Бакинской и Елизаветпольской губерниях Азербайджана и русском Туркестане. Инициатором создания «Джаридат Дагистан» был военный губернатор Дагестанской области генерал-лейтенант С.В. Вольский (1908-1916), собиравшийся сделать ее официальным органом российской администрации, в котором должны были перепечатываться материалы из «Дагестанских областных ведомостей». Газета должна была служить «просвещению» мусульман области и распространению среди них цивилизаторских идей русских властей. Однако не все эти планы осуществились. Газета перепечатывала в переводе лишь отдельные важные постановления и материалы из русских периодических изданий, но русского оригинала у нее так и не появилось. С 1914 г. ввиду убыточности издания все расходы по ее публикации взял на себя Бадави Саидов (1877-1927) из селения Чох, начальник Канцелярии военного губернатора области, председатель Общества просвещения туземцев-мусульман. Большую помощь ему оказывал его земляк Мухаммад-мирза Мавраев (1878-1964), знаменитый дагестанский первопечатник. Все номера газеты литографированы в его Исламской типографии.

Одним из ведущих сотрудников газеты с первых ее номеров стал дагестанский джадид Али Каяев ал-Гумуки (1878-1943) из лакского селения Кумух, известный дагестанский мударрис, популяризатор научных знаний. Он сразу же взял на себя все заботы о редактировании издания, а с января по март 1918 г. занимал пост официального редактора газеты. Его перу принадлежит большинство опубликованных в «Джаридат Дагистан» статей. Через газету Каяев пропагандировал идеи мусульманского реформаторства (алислах), выступая за введение в школах при мечетях новых методов обучения (асалиб ат-та'лим ал-джадида). Взгляды фактического редактора газеты разделял целый ряд дагестанских улемов. Из них прежде всего следует назвать Мухаммада Дибирова, Ахмада Каради Закуева из Кумуха, Абу Суфйана Акаева, известного аварского поэта и ученого Гамзата Цадаса, Аскар-кади из Дженгутая, Мас'уда из Могоха, Муртаду из Кудали, Са‘ида Габиева, накшбандийского и шазилийского шейха Сайфуллаха-кади из Ницовкры под Кумухом, Мас'уда из Чечни. На страницах газеты разворачивались ожесточенные споры между джадидами и их противниками по поводу правовых и богословских проблем ислама, повседневной обрядовой практики мусульман, их места в современном мире, народного образования [Наврузов, 2003. С. 27-29]. 
После окончания Гражданской войны и создания в составе Советской России Дагестанской АССР в том же Буйнакске появился журнал на арабском языке «Байан ал-хака'ик». С сентября 1925 по август 1928 г. его издавал другой не менее известный дагестанский джадид и бывший корреспондент «Джаридат Дагистан» Абу Суфйан Акаев (1872-1931) из кумыкского селения Нижнее Казанище. Членами редколлегии были дагестанские улемы Йусуф-кади из Дженгутая, Хаджжи-кади из Казанище, Билал-Хаджи из Дженгутая, Мустафа-кади и Хизри из Казанище. Среди читателей и корреспондентов журнала были также суфии. Кроме статей дагестанских авторов в журнале печатались полемические работы известных на Северном Кавказе улемов арабского Ближнего Востока, таких как 'Абд ал-Ваххаб ашШа'рани, современные исламские модернисты Мухаммад 'Абдо и Рашид Рида. Последние, как правило, сопровождались комментариями редакционной коллегии, по большей части, самого главного редактора Абу Суфйана Акаева. Журнал выходил при поддержке советских властей республики и совершенно легально печатался в советской Типо-литографии Даггосиздата имени Гоголева тиражом 1000-1050 экземпляров. Журнал планировался как ежемесячный, но фактически издавался раз в три-четыре месяца. Всего вышло 12 номеров. Издание прекратилось с началом наступления окрепшей советской власти на религию на восточных окраинах СССР и развертыванием массовых политических репрессий, в которых погибли виднейшие представители джадидизма, включая редакторов обоих изданий.

Журнал «Байан ал-хака'ик» (как говорит само его название) имел целью разъяснить и обосновать в свете шари'ата культурные и социально-экономические преобразования, начатые советским правительством [Байан ал-хака'uк, 1925. № 1. С. 1]. В этом характерном джадидском издании много места уделялось реформе народного образования, созданию для мусульман советского Востока доступной и массовой общеобразовательной школы, ликвидации неграмотности, освещению событий в мусульманском мире за рубежом, где в это время шли колоссальные перемены, связанные с распадом Османской империи, ликвидацией в 1924 г. Мустафой Кемалем Ататюрком халифата, подъемом антиколониального движения. Большое место в нем занимали волновавшие и в то время улемов Дагестана проблемы современного толкования исламской религиозно-правовой традиции ( $а т$-таклид). Структура и содержание номеров журнала во многом напоминают рубрики «Джаридат Дагистан». Здесь также обсуждались вопросы религиозного быта и обрядности, включая обычай вторичного коллективного намаза после пятничной проповеди-хутбы, чтение последней на арабском и языках народов Северного Кавказа, запрет изображений человека в исламе в свете современного быта, горские обычаи и общие обязанности шари'ата для мусульман. Были в журнале и новые темы, такие как вопрос об отношении мусульман к советской власти, революционному 
движению против колонизаторов за рубежом, правомочности духовной власти и передачи наставничества в распространенных на Северном Кавказе суфийских братствах накшбандийа, шазилийа и кадирийа [Наврузов, 2011. С. 19-26].

Одной из центральных проблем, обсуждавшихся дагестанскими и северокавказскими улемами на рубеже дореволюционной царской и советской эпох был иджтuхад - право высших авторитетов в вопросах шари'ата (муджтахидов) выносить самостоятельные решения на основе Корана, сунны и методов исламского права (фuкx), заключающийся в выборе правовых источников, их сравнительном толковании, классификации правовых аргументов и методов, казуистическом разборе спорных и нерешенных в Коране и сунне вопросов, и затем выработке общих норм их решения. Их занимал вопрос, насколько мусульмане обязаны следовать традиции, выраженной в трудах основоположников религиозно-правовых школ (мазхабов), включая господствующую традиционно в Дагестане шафиитскую религиозно-правовую школу.

Дагестанские джадиды полагали, что таклид необходимо творчески менять с учетом насущных проблем современного общества. Они уверяли своих оппонентов и читателей, что возврат к иджтихаду совсем не означает неуважения к исламскому наследию, не говоря про вероотступничество, в чем джадидов нередко обвиняли оппоненты из лагеря традиционалистов, а наоборот, способствует возрождению исламского мира, помогая его освобождению от власти колониальных европейских держав и иных угнетателей мусульман. При этом они любили ссылаться на опыт выдающихся дагестанских богословов и ученых-энциклопедистов начала Нового времени, прежде всего Мухаммада б. Мусы ал-Кудуки (1652-1717) из Кудутля. Как известно из дошедших до нас сочинений Кудутлинского и дагестанских биографических словарей, в догматике он придерживался системы основоположника исламской схоластики ал-Аш'ари (873-935), а в исламском праве - школы имама аш-Шафи“и (767-820). Однако он не считал себя обязанным бездумно следовать идущей от них традиции (таклид), но по примеру своего учителя, известного в то время на Арабском Востоке ученого Салиха ал-Йамани «прибегал к иджтихаду» [Шихсаидов, 2006. С. 223].

Уже в советское время автор известного биографического словаря дагестанских улемов Назир ад-Дургели (1891-1935) обратился к ученым Дагестана с просьбой сообщить ему свои соображения относительно иджтихада и таклида в современности [Назир ад-Дургели. Ат-Та'лик ал-хамид. См. также: Шихсаидов, Омаров, 2005. С. 45]. Отвечая откликнувшемуся на его призыв шейху Йусуфу-кади из Дженгутая, Назир на примере Кудутлинского и других дагестанских улемов показывал, что мусульманские ученые Дагестана много веков после «закрытия врат иджтихада», как это утверждает распространенное клише, «много и подробно писали... об ал-иджтихаде и ат-таклиде» При этом он полагал, что «иджтихад в какой-то мере сохранил- 
ся лишь при решении частных, предельно легких проблем» [Назир ад-Дургели [1920-е гг.]. См. также: Шихсаидов, Омаров, 2005. С. 42]. В свою очередь, Йсуф ал-Джункути писал о необходимости отличать абсолютный (мутлак) иджтихад от относительного иджтихада (мунmaсuб) муджтахидов вроде арабских улемов ал-Мазани, Ибн Хазима, Ибн Сурайджа, фактически основывавшихся на достижениях полного иджтихада имамов мазхабов. Поэтому, по его мнению, «муджтахиды первой ступени (мутлак) исчезли уже со времени четырех имамов [мазхабов]» [Йусуф ал-Джункути, Ал-Каул ас-садид. См. также: Шихсаидов, Омаров, 2005. С. 44]. Мнение обоих улемов по проблеме абсолютного иджтихада в целом совпадало, но они не соглашались в оценках деятельности разных ученых Дагестана. Поэтому в ответном письме Назир ад-Дургели отметил слабость аргументов Йусуфа из Дженгутая, при всех его ученых и ораторских талантах без оснований «нападавшего на некоторых имамов» и опиравшегося к тому же на слабые хадисы [Назир ад-Дургели. Ат-Та'лик ал-хамид]. В свою очередь, Дженгутайский упрекал Назира в уклонении от согласного мнения исламских ученых и фактическом отходе от истин ислама. На эту же тему Назир ад-Дургели спорил с Мухаммадом ат-Таргули из с. Тарки [Шихсаидов, Омаров, 2005. С. 113].

На страницы северокавказской исламской прессы эту полемику перенес уже упоминавшийся выше публицист-джадид Али Каяев. По его мнению, иджтихад отнюдь не прекратился после деятельности имамов, от которых ведут свое начало мазхабы суннитского ислама. Немало выдающихся имамов, таких как автор «Ал-Мухаззиб» Абу Исхак, улемы Ирака, Хорасана вроде ал-Джувайни, разных маликитских и ханафитских правоведов и других ученых в самых различных странах мусульманского мира и позднее выносили фетвы об иджтихаде по различным вопросам ['Али ал-Гумуки, 1913. С. 3-4]. В подтверждение своего убеждения о необходимости иджтихада вплоть до современности Каяев ссылался на мнение шейха 'Абд алХаййа ал-Кахнави ал-Хинди в труде «Ан-Нафи“ ал-кабир ли ман йутали' ал-джами' ал-сагир», на сочинение Ал-Хафиза б. 'Абд ал-Бирра «Джами' байан ал-‘илм ва фадли-х», а также известные работы ас-Субки и ас-Суйути ['Али ал-Гумуки, 1915. С. 4].

Свой вклад в обсуждение проблемы следования религиозной традиции внесли суфийские наставники раннего Советского Дагестана. Среди них выделяется влиятельный накшбандийский и шазилийский шейх Хасан ал-Хилми ал-Кахи (ум. 1937) из Кахиба, письма которого в раннее советское время печатались в «Байан ал-хака'ик». Он подробно разбирает эту проблему в изданной уже в постсоветское время книге «Ал-бурудж ал-мушаййада», резко осуждая тех улемов, кто не признает закрытия врат иджтихада и отказывается следовать одному из четырех суннитских мазхабов. В резко полемической форме он говорит о них, «что... к иджтихаду призывает сегодня только тот, кто не в своем уме 
и испорчен в вере» [Хасан ал-Хилми ал-Кахи, 1996. С. 332-333]. Сам он оставался в лагере сторонников таклида, полагая что правоверному мусульманину пристает следовать в понимании Корана, сунны и иных источников исламского права авторитетам того мазхаба, которого традиционно придерживаются в месте, где он живет и работает.

В середине 1920-х годов проблема следования религиозной традиции публично обсуждалась на ряде мероприятий, проведенных мусульманскими улемами при поддержке советской власти. Об этом свидетельствует речь бывшего корреспондента Каяева в газете «Джаридат Дагистан» Абу Мухаммада Мас'уда из с. Могох, написанная для II съезда улемов Дагестана, состоявшегося в феврале 1925 г. в Темир-Хан-Шуре 2 . В ней он призывал мусульман к проведению серьезных реформ в судопроизводстве, идейной независимости и освобождению исламского богословия от оков таклида, современному пониманию религии, свободному от ошибок минувших поколений. В его речи есть и призыв к открытию врат иджтихада. К этому, по его мнению, подводит совершающиеся на глазах перемены в мусульманском обществе, появление новых социальных и культурных реалий, найти аналогии которым в исламской традиции затруднительно. Мас'уд хорошо понимал невозможность иджтихада для каждого мусульманина, и даже всех делегатов съезда, признавая, что это приведет к анархии и извращению установлений шари'ата. Не собирался он применять иджтихад к основам вероучения и исламской обрядности. Право иджтихада он собирался ограничить довольно узким кругом современных улемов, которые достигли ступени настоящих муджтахидов. При этом он предлагал отличать подлинных муджтахидов от муджтахидов мнимых, слепо и бездумно копирующих идущую от минувших поколений традицию, без обращения к изучению установлений Корана и сунны. Последние псевдомуджтахиды для него - «слепцы. А слепец не годится для того, чтобы быть поводырем у слепых, которых лучше проведет даже животное...» [Ибрахим Хаджияв ар-Рукни ат-Таймири. С. 15-17. См. также: Байан ал-хака'uк. 1927, № 7. С. 6, 11].

В чем-то похожей позиции придерживался дагестанский ученый 'Абд ар-Рахим ал-Аймаки, посвятивший этой проблеме главу в своей книге «Кунуз ал-ахкам». Здесь он собрал и прокомментировал немало цитат противников слепого следования религиозной традиции. К такому умозаключению, по его мнению, подводят даже айаты Корана (2:85). При этом Аймакинский призывает различать таклид авторитетных ученых прошлого от бессмысленного подражания всему, освященному древностью. Для него такая позиция приближается к идолопоклонству, сурово осуждаемому в исламе. «...Как омерзительно подражание и высказывание, принимаемое без доказательств. Как

2 | См.: датированное 1343 г.х. письмо Мухаммада ал-Чиркати в личной библиотеке Чарана Чаранова в с. Могох Гергебильского района Республики Дагестан. 
велики козни шайтана для подражателей, - пишет он, - когда он завлекает их, чтобы они подражали своим предкам в поклонении своим идолам. Они же убеждены, что достигли чего-то, трудятся в победе своего мазхаба, спорят с поборниками истины, думая, что правы они. Для поборников традиции достаточно оскорбления, что рабы идолов есть среди них» ['Абд ар-Рахим ал-Аймаки, б.г.].

Так сложно и противоречиво развивалась дискуссия о значении религиозной традиции и возможных ответах мусульманского сообщества в лице своих ученых на вызовы современности в Дагестане первой четверти XX в. Многие суждения и попытки решения ее не устарели до сих пор. Эта проблема была и остается предметом споров исламских ученых региона, приобретших особую актуальность в контексте острой идеологической борьбы между салафитами и традиционалистами постсоветской эпохи.

\section{Список сокращений}

РФ ИИАЭ - Рукописный фонд Института истории, археологии, этнографии Дагестанского научного центра Российской академии наук.

ФMC - Фонд Магомед-Саида Саидова. Махачкала. 


\section{Источники и литература}

'Абд ар-Рахим ал-Аймаки, б.г. - 'Абд ар-Рахим ал-Аймаки. Кунуз ал-ахкам фи муназарат ал-а'лалам // Рукопись в личной библиотеке Нурмагомеда Нурмагомедова Араканского в г. Махачкала.

'Али ал-Гумуки, 1913 - 'Али ал-Гумуки. Ал-иджтихад ва-т-таклид // Джаридат Дагистан (Темир-Хан-Шура). 1913. № 31. С. 3-4.

'Али ал-Гумуки. 1915 - 'Али ал-Гумуки. Ал-иджтихад ва-т-таклид // Джаридат Дагистан (Темир-Хан-Шура). 1915. № 41, 42.

Байан ал-хака'ик, 1925. № 1 - Байан ал-хака'ик (Буйнакск). Сентябрь 1925 / Раби алаввал 1344 г. № 1.

Ибрахим Хаджияв ар-Рукни ат-Таймири, 1927 - Ибрахим Хаджияв ар-Рукни ат-Таймири. Рассуждение о порицании традиции (таклид) (араб) // Байан ал-хака'ик (Буйнакск). 1927. № 6.

Йусуф ал-Джункути, Ал-Каул ас-садид - Йусуф ал-Джункути. Ал-Каул ас-садид фи хасм маддат ал-иджтихад ва-т-таклид // РФ ИИАЭ. ФМС. № 356.

Назир ад-Дургели, [1920-е гг.] - Назир ад-Дургели. Рисалат ал-иджтихад ва-т-таклид [1920-е гг.] // РФ ИИАЭ. ФМС. № 35а.

Назир ад-Дургели. Ат-Та'лик ал-хамид - Назир ад-Дургели. Ат-Та'лик ал-хамид 'ала алкаул ас-садид // РФ ИИАЭ. ФМС. № 35в.

Наврузов, 2003 - Наврузов А.Р. «Джаридат Дагистан» // Ислам на территории бывшей Российской империи: Энциклопедический словарь / Отв. ред. и сост. С.М. Прозоров. Вып. 4. М., 2003. С. 26-29.

Наврузов, 2011 - Наврузов А.P. «Байан ал-хака'ик» - печатный орган ученых-арабистов Дагестана первой трети XX века // Pax islamica. 2011. № 2. С. 19-26.

Наврузов, 2012 - Наврузов А.P. «Джаридат Дагистан» - арабоязычная газета дагестанских джадидов. М., 2012.

Хасан ал-Хилми ал-Кахи, 1996 - Хасан ал-Хилми ал-Кахи. Ал-бурудж ал-мушаййада би-ннусус ал-муаййида. Дамаск, 1996.

Шихсаидов, 2006 - Шихсаидов А.Р. Ал-Кудуки // Ислам на территории бывшей Российской империи: Энциклопедический словарь / Под ред. С.М. Прозорова. Т. І. М., 2006.

С. 222-223.

Шихсаидов, Омаров, 2005 - Шихсаидов А.Р., Омаров Х.А. Каталог арабских рукописей (Коллекция М.-С.Саидова). Махачкала, 2005. 